\title{
Atrofi ve proksimal kas güçsüzlüğü olan olgu: seronegatif Lambert Eaton Myastenik Sendrom
}

\author{
Case with atrophy and proximal muscle weakness: seronegative Lambert Eaton \\ Myasthenic Syndrome
}

Bahar Say, Ufuk Ergün, Gülten Karaca

Gönderilme tarihi: 14.07 .2018

Kabul tarihi:17.10.2018

\begin{abstract}
Özet
Lambert Eaton Myastenik Sendrom (LEMS) proksimal kas güçsüzlüğü, reflekslerde azalma veya kayıp, ılımlı oküler bulgular ve otonom bulgular ile seyreden presinaptik voltaj bağımlı kalsiyum kanallarına antikor gelişimi ile karekterize nadir görülen nöromuskuler kavşak hastalığıdır. Paraneoplastik veya otoimmün olabilir. Paraneoplastik LEMS en sık küçük hücreli akciğer kanseri ile birliktelik gösterir. Primer otoimmun olarak ise diyabet, romatoid artrit, sistemik lupus eritematozus, otoimmun tiroid hastalıklarıyla birliktelik gösterebilir. Tanı klinik bulgular ve elektrofizyolojik olarak ardışık sinir uyarım testi veya tek lif elektromyelografi ile konur. Tedavisinde olguya göre 3,4 diaminopiridin, Intravenöz immunglobulin, plazmaferez, prednizolon ve azotiopürin yer alır.
\end{abstract}

Anahtar Kelimeler: Proksimal kas güçsüzlüğü, otonom bulgular, Lambert Eaton Myastenik Sendromu.

Say B, Ergün U, Karaca G. Atrofi ve proksimal kas güçsüzlüğü ile başvuran olgu: seronegatif Lambert Eaton Myastenik Sendrom. Pam Tıp Derg 2019;12:181-183.

\begin{abstract}
Lambert Eaton Myasthenic Syndrome (LEMS) is a rare neuromuscular junction disease characterized by proximal muscle weakness, decrease or loss of reflexes, moderate ocular and autonomic findings with antibody development to presynaptic voltage-dependent calcium channels. It can be paraneoplastic or autoimmun. Paraneoplastic LEMS is most commonly associated with small-cell lung cancer. Primary autoimmune may be associated with diabetes, rheumatoid arthritis, systemic lupus erythematosus, autoimmune thyroid diseases. Diagnosis is based clinical findings and electrophsyologic studies include repetetif nerve stimulation or single fiber electromyelography. Treatment includes 3,4 diaminopyridine, intravenous immunglobulin, plasmapheresis, prednisolone and azothiopurine according to the case.
\end{abstract}

Key words: Proximal muscle weakness, autonomic findings, Lambert Eaton Myasthenic Syndrome.

Say B, Ergün U, Karaca G. Case with atrophy and proximal muscle weakness: seronegative Lambert Eaton Myasthenic Syndrome. Pam Med J 2019;12:181-183.

\section{Giriş}

Lambert Eaton Myastenik Sendromu (LEMS) presinaptik asetilkolin salınım bozukluğu ile karakterize nadir görülen nöromuskuler kavşak hastalığıdır. Prevelansı dünya çapında her bir milyon insanda 3-4'dür. Paraneoplastik veya primer otoimmün olarak görülebilir. Paraneoplastik LEMS en sık küçük hücreli akciğer kanseri ile birliktelik gösterir. Paraneoplastik LEMS de başlangıç yaşı ortalama 60 iken otoimmün olanda 50 yaştır [1].
Eaton ve Lambert [2] tarafından 1957 yılında ardışık sinir uyarım testi ile farklı elektrofizyolojik özellikler gösteren LEMS ortaya konulmuştur. Hastalıkta nöromusküler kavşaktaki presinaptik sinir terminallerindeki $P Q$ tipi voltaj bağımlı kalsiyum kanallarına (VGCC) karşı antikor nedeniyle asetilkolin salınımında azalma, buna bağlı olarakta kas güçsüzlüğü görülür. Güçsüzlük proksimal kaslarda hâkimdir. Derin tendon reflekslerinde azalma veya kayıp, ağız kuruluğu, konstipasyon, ortostatik disfonksiyon, bulanık görme, pitoz, disfaji diğer bulgular arasındadır. Tanı klinik ve elektrofizyolojik olarak

Bahar Say, Dr. Öğr. Üyesi, Kırıkkale Üniversitesi Tıp Fakültesi Nöroloji AD. KIRIKKALE, e-posta:drbaharsay@gmail.com (orcid.org/0000-0003-25953804) (Sorumlu yazar)

Ufuk Ergün, Prof. Dr. Kırıkkale Üniversitesi Tıp Fakültesi Nöroloji AD. KIRIKKALE, e-posta:ufukergun@yahoo.com (orcid.org/0000-0002-2664-1549) Gülten Karaca, Prof. Dr. Kırıkkale Üniversitesi Fizik Tedavi ve Rehabilitasyon AD. KIRIKKALE, e-posta:gulten2013@yahoo.com (orcid.org/00000002-2036-4050) 
konulur. Tedavide tümoral bir neden varsa ona ait tedavi, pridostigmin, 3-4 diaminopridine, hızlı ilerleyen olgularda intravenöz ımmunglobulin, plazmaferez, yeterli kontrol sağlanamayan olgularda ise prednizolon ve azotiopurin önerilmektedir [3].

\section{Olgu Sunumu}

Otuz yaşında kadın hasta sağ tarafında belirgin olmak üzere genel güçsüzlük ve düşme, saçını tarayamama, merdiven çıkmada zorluk, sık sık düşme ve sağ bacakta incelme yakınması ile polikliniğimize başvurdu. Yakınmaları 2 yıl önce başlamış, bir miktarda artış göstermesi üzerine doktora başvurmuştu. Bu nedenle dış merkezde yapılan biyokimyasal değerler, tam kan sayımı,vitamin B12, tiroid fonksiyon testleri ve otoantikorları normaldi. Özgeçmişinde özellik yoktu. Soygeçmişinde abisinde lenfoma, anannesinde kolon kanseri mevcuttu. Nörolojik muayenesinde kas gücü sağ üst ve alt ekstremitedeproksimal $3+/ 5$ distal 5-/5 sol üst ve alt ekstremitede proksimal 4+/5 distal 5-/5 kuvvet mevcuttu. Yaygın hiporefleksi olup, sağ bacakta patella altından ve sağ kolda deltoid kas orta noktasından ölçümde ekstremite çapı sola göre $2 \mathrm{~cm}$ azdı (Resim 1). Diğer muayene bulguları normal sınırlardaydı. Hastaya öncelikle miyopati ön tanısı ile elektromiyelografi (EMG) yapıldı. Sinir ileti çalışması normal olup proksimal kaslarda, polifazik düşük amplitüdlü, miyopatik motor ünit potansiyelleri (MÜP) görülmesi üzerine kas biyopsisi önerildi. Dış merkezde yapılan biyopsi de patoloji gözlenmedi. Fizik tedavi programına alındı. İzleminde ara sıra bulanık görme ve göz kapaklarında düşme ile ağız kuruluğu başladığını belirten olgunun muayenesinde ek olarak sağ lateral bakışta nistagmus gözlendi. Hastaya nöromuskuler kavşak hastalığı ön tanısı ile ardışık sinir uyarım (ASU) incelemesi yapıldı. Sol abduktor digiti minimi kası kayıtlı ASU' da 20, $30 \mathrm{~Hz}$ 'de patolojik inkrement yanıt ve amplitüd artışı izlendi (Resim 2). $50 \mathrm{~Hz}$ uyarımı hasta tolere edemedi. LEMS tanısı ile bakılan $P Q$ ve $\mathrm{N}$ tipi kalsiyum kanal antikoru negatif olup paraneoplastik taramada, toraks ve abdomen tomografi, pozitron emisyon tomografi (PET), kolonoskopi, meme ve jinekolojik değerlendirmesinde patoloji saptanmadı. Ayrıca paraneoplastik antikor taraması, vaskülit belirteçleri ve fizik tedavi bölümünce yapılan romatolojik hastalık taraması negatifdi. Tedavide pridostigmin yanıtı olmadı. Kas güçsüzlüğü ve düşmeleri artan olguya intravenöz immünglobulin uygulandı. 3,4 diaminopridin tedavisi ve 6 ayda bir paraneoplastik tarama planlanarak izleme alındı.

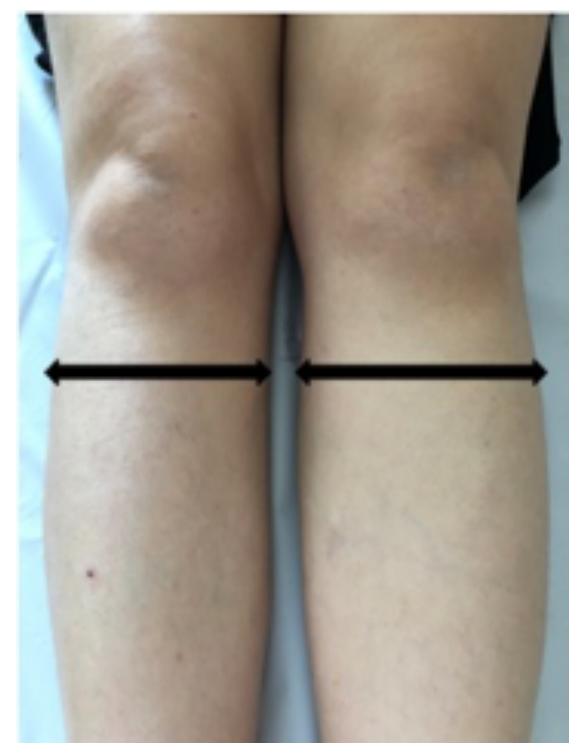

Resim 1. Sağ alt ekstremite çapında sol ekstremiteye göre azalma

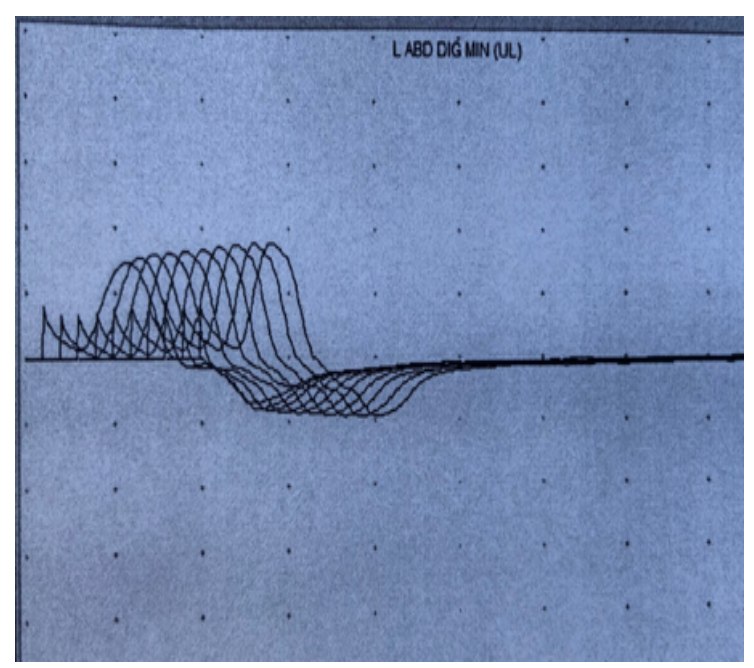

Resim 2. $20 \mathrm{~Hz}$ Ardışık sinir uyarım testinde sol abductor digiti minimi kasında inkrement yanıt

UL:ulnar ABD DIG MIN:Abductor digiti minimi 


\section{Tartışma}

Lambert Eaton Myastenik Sendrom tanısı klinikte gözlenen proksimal kas güçsüzlüğü ile derin tendon reflekslerinde azalma ve diğer ek bulgular yanında elektrofizyolojik çalışmalarda ASU ve tek lif EMG ile konulmaktadır. ASU da düşük frekanslı uyarımlarda kas aksiyon potansiyelinde dekrement yüksek frekanslı uyarımlarda inkrement LEMS için tipiktir. Ancak olgularda proksimal kas güçsüzlüğü bazen eşlik eden atrofi miyopati tanısı düşündürebilir. Ayrıca iğne EMG'de miyopatik MÜP gözlenmesi de bu tanıyı destekleyebilir. Corne ve ark.[4] LEMS tanılı 4 bayan olguda Komatsu ve ark. [5] ise 8 LEMS olgusunun altısında EMG'de miyopatik değişiklikler saptamıştır. İğne EMG 'deki bu değişikliklerin sebebi sinir ucu terminallerinden salınan asetilkolinin azalması ve buna bağlı olan son plak potansiyelin azalmasıdır [5]. Literatürde 23 yaşında klinik ve elektrofizyolojik olarak miyopati tanısı düşünülen ancak 50 yaşında LEMS tanısı doğrulanan bir olgu bildirilmiştir [6]. Bizim olgumuzda klinik ve elektrofizyolojik olarak miyopati düşündüren semptomlar olup ayrıca sağ alt ve üst ekstremitede atrofisi mevcuttu. Kas biyopsisi normal olan olguda izleminde ağız kuruluğu, ara sıra olan göz kapağında düşme ve bulanık görme yakınmaları, LEMS tanısını akla getirmiş ve ASU ile de tanı doğrulanmıştır. LEMS de kas atrofisinin, hastalığa özgü olmayıp kullanmamaya bağlı olduğu düşünülmektedir [4].

Paraneoplastik veya primer otoimmün olarak ortaya çıkabilen LEMS'de, voltaj bağımlı kalsiyum kanallarına karşı antikor bulunması, olguların \%85 ile 95'inde gözlenmektedir [7]. PQ tipi antikorların küçük hücreli akciğer kanseri ile ilişkili LEMS 'de \%100'e kadar, malignensi eşlik etmeyen grupta ise \%90'a kadar pozitif olabileceği bildirilmiştir [3]. PQ tipi antikora ek olarak $\mathrm{N}$ tipi kalsiyum kanal antikorunun da akciğer kanseri ve LEMS birlikteliğinde gözlenebileceği bilinmektedir [8]. Bizim olgumuzda her iki antikor negatif olarak bulunmuştur. Ayrıca ilk taramada paraneoplastik belirteçler negatif olup, toraks ve batın bilgisayarlı tomografisi ile jinekolojik taramasında patoloji gözlenmedi. Olgumuzda 2 yıla kadar 6 ayda bir paraneoplastik taramanın tekrarı planlandı. Paraneoplastik olmayıp primer otoimmün olarak da gözlenebilen LEMS otoimmün tiroid hastalığı, diyabet, romatoid artrit, sistemik lupus eritematozus ile birliktelik olabilmektedir [1]. Vaskülit belirteçleri, tiroid otoantikorları negatif olan olgumuzda romatolojik hastalık açısından fizik tedavi bölümünce yapılan tetkiklerindede patolojik sonuç görülmedi.

Sonuç olarak proksimal kas güçsüzlüğü ile gelen olgularda nadir görülen LEMS' in akılda tutulması, klinik bulgular açısından hastanın sorgulanması ve izleminin önem taşıdığının vurgulanması amacıyla bu olgu sunulmaya değer bulunmuştur.

Çıkar İlişkisi: Yazarlar çıkar ilişkisi olmadığını beyan eder.

\section{Kaynaklar}

1. Schoser B, Eymard B, Datt J, Mantegazza R. Lambert-Eaton myasthenic syndrome (LEMS): a rare autoimmune presynaptic disorder often associated with cancer. J Neurol 2017;264:1854-1863.

2. Eaton LM, Lambert EH. Electromyography and electric stimulation of nerves in disease of the motor ünit: observations on a myastenic syndrome associated with malignant tumours. J Am Med Assoc 1957;163:11171124

3. Kesner VG, Oh SJ, Dimachkie MM, Barohn RJ. Lambert-eaton myasthenic syndrome. Neurol Clin 2018;36:379-394.

4. Crone C, Christiansen I, Vissing J. Myopathic EMG findings and type II muscle fiber atrophy in patients with Lambert-Eaton myasthenic syndrome. Clin Neurophysiol 2013;124:1889-1892.

5. Komatsu T, Bokuda K, Shimizu T, Komori T, Koide R. Pseudomyopathic changes in needle electromyography in lambert-eaton myasthenic syndrome. Case Rep Neurol Med 2013;369278.

6. Gökçal E, Gürsoy AE, Asil T, Ertaş M. Lambert-Eaton Myasthenic Syndrome with a twenty-three-year delay in diagnosis. Noro Psikiyatr Ars 2017;54:189-190.

7. Oh SJ, Hatanaka Y, Claussen GC, Sher E. Electrophysiological differences in seropositive and seronegative Lambert-Eaton myasthenic syndrome. Muscle Nerve 2007;35:178-183.

8. Zalewski NL, Lennon VA, Lachance DH, Klein CJ, Pittock SJ, Mckeon A. P/Q- and N-type calcium-channel antibodies: oncological, neurological, and serological accompaniments. Muscle Nerve 2016;54:220-227. 